\begin{tabular}{lll} 
KULTURA & $\begin{array}{l}\text { POLSKA A KADEMIA NAUK } \\
\text { KOMITET SOCJOLOGII }\end{array}$ & ISSN 0023-5172 \\
i & $\begin{array}{l}\text { INSTYTUT STUDIÓW POLITYCZNYCH } \\
\text { SPOLCLENSTWO nr } 2016, \text { WIDZIANE W MIEŚCIE }\end{array}$ & \\
\hline
\end{tabular}

MAREK NOWAK

Uniwersytet im. Adama Mickiewicza w Poznaniu

\title{
STUDENTYFIKACJA — REKONCEPTUALIZACJA POJĘCIA I HIPOTEZY BADAWCZE
}

W centrum zmiany, która dokonywała się w latach osiemdziesiątych i dziewięćdziesiątych XX wieku w tzw. zachodnim kręgu cywilizacyjnym, znajdował się wzrost znaczenia kontekstu globalnego w ewolucji miast. W literaturze poświęconej miastom analiza tego procesu sąsiadowała (czy raczej nadal sąsiaduje) z refleksją na temat metropolizacji, przy czym szczególną uwagę poświęcano „użytkownikom zewnętrznym” (zob. Martinotti 1996), sieciowości i informacji. Jednocześnie podkreślanie znaczenia kontekstu zewnętrznego (globalnego podziału pracy), wiedzy i jej zdobywania w pewien sposób deprecjonowało sferę produkcji materialnej i castellsowską (nowoczesną) wizję miasta, które można nazwać "samoistnym" ${ }^{1}$ (zob. pracę Kwestia miejska z lat siedemdziesiątych XX wieku; Castells 1982). W wyłaniającym się w latach sześćdziesiątych obrazie społeczeństwa dobrobytu, a następnie $\mathrm{w}$ latach osiemdziesiątych, gdy upowszechniały się symptomy postnowoczesnego kapitalizmu (i społeczeństwa postindustrialnego), znaczącą rolę odgrywali studenci oraz uniwersytety, z właściwą dla żaków z jednej strony labilnością, z drugiej zaś zdolnością do przystosowania ${ }^{2}$. Ich obecność w życiu społecznym stała się jednym

Adres do korespondencji: marek.nowak@amu.edu.pl

${ }^{1}$ Pojęcie stosowane $\mathrm{w}$ opisach specyfiki greckiego miasta-państwa jako makrostruktury społecznej (zob. Rybicki 1979).

2 Ta specyficzna rola gotowości do radykalnej zmiany (przykład rewolt studenckich końca lat sześćdziesiątych XX wieku) i zarazem woli „wchodzenia” w istniejące już relacje (to już lata osiemdziesiąte i dziewięćdziesiąte) może ilustrować „kaskadę” zmian społecznych (lub tzw. efekt kaskady). Chodzi o procesy, w toku których nawet stosunkowo niewielka zmiana, obok wielu innych, prowadzi do ewolucji całego systemu. Z pojęcia tego korzystano w analizie historycznej odrębności 
z istotnych elementów stosunków społecznych. Było i jest tak choćby z racji ich masowej obecności. O innych oddziaływaniach wiemy zaskakująco niewiele, szczególnie w rodzimym środkowoeuropejskim kontekście. Przedstawione opracowanie jest zatem próbą ujęcia tytułowego zagadnienia w nowy sposób i w konsekwencji zawiera szereg pytań badawczych i szereg szczegółowych hipotez. Rozważania zostały oparte na rodzimych doświadczeniach, przy założeniu konwergencji procesów zachodzących w naszym kraju i w szerszym kręgu cywilizacyjnym.

\section{MASOWA OBECNOŚĆ STUDENTÓW W POLSKICH MIASTACH}

W Polsce skłonność do studiowania wykazuje ciekawą dynamikę: da się ją opisywać (za pomocą systematycznie zbieranych danych) jako „koincydencję” bądź związek (wprost proporcjonalny) z procesem transformacji systemowej. W ciągu 25 lat mamy do czynienia $z$ systematycznym wzrostem liczby studentów, który osiągnął apogeum w latach 2006-2008. Najliczniejsza grupa absolwentów opuściła uczelnie wyższe nieco później, w latach 2010-2013. Można sądzić, że to wtedy — w latach 2006-2013 — oddziaływanie decyzji edukacyjnych młodych Polaków było największe.

Zarejestrowane dane liczbowe wskazują na potencjalnie znaczące konsekwencje opisywanego zjawiska dla sfer polityki społecznej, a także dla wielu innych obszarów o podstawowym znaczeniu w życiu zbiorowości. Obrazuje to krzywa liczebności studentów w polskich szkołach wyższych (zob. wykres 1).

Nieco odmienny kształt ma krzywa obrazująca zmiany współczynnika skolaryzacji netto (zob. wykres 2). Wskaźnik ten wyraźnie rośnie w latach dziewięćdziesiątych XX wieku, by niemal całe kolejne dziesięciolecie utrzymywać się na poziomie bez mała 40\% (co oznacza, że niemal połowa młodych osób podejmuje studia), a o liczbie studentów decyduje nie tyle falująca skłonność do studiowania (ta rosła i ustabilizowała się na wysokim poziomie), ale spadkowy trend demograficzny. Apogeum współczynnik ten osiągnął w 2010 roku, by zacząć opadać w roku 2013. Co interesujące, postępujący później spadek nie jest znaczący. Ostatnie dwa lata wydają się znamionować pewną ewolucję, o której kierunku trudno jeszcze jednoznacznie orzekać.

Warto zwrócić uwagę, że liczba studentów w największych miastach Polski sięga (od początku drugiej dekady nowego millenium) 1/5 populacji i nie jest najwyższa w najsilniejszych ekonomicznie ośrodkach. Intrygujący przykład stanowi województwo lubelskie ${ }^{3}$, gdzie proporcjonalny udział studentów w re-

rozwojowej Europy Środkowej (zob. Brzechczyn 1998). W przywołanym użyciu stanowi propozycję ujęcia roli jednego szczegółowego czynnika, który oddziałuje na proces ewolucji miasta. W pewnym sensie jest zarówno przyczyną, jak i skutkiem zmian obserwowanych na poziomie systemu społecznego.

${ }^{3}$ Dane z raportu delegatury GUS wskazują, że w latach 2012/2013 było tu ponad 91 tys. studentów, w 2013-2014 blisko 85 tys., dla populacji 183 tys. osób w wieku 19-24 lata (zob. 
Liczba studentów od 1991 roku (wraz z prognozą GUS) oraz liczba absolwentów wyższych uczelni w Polsce

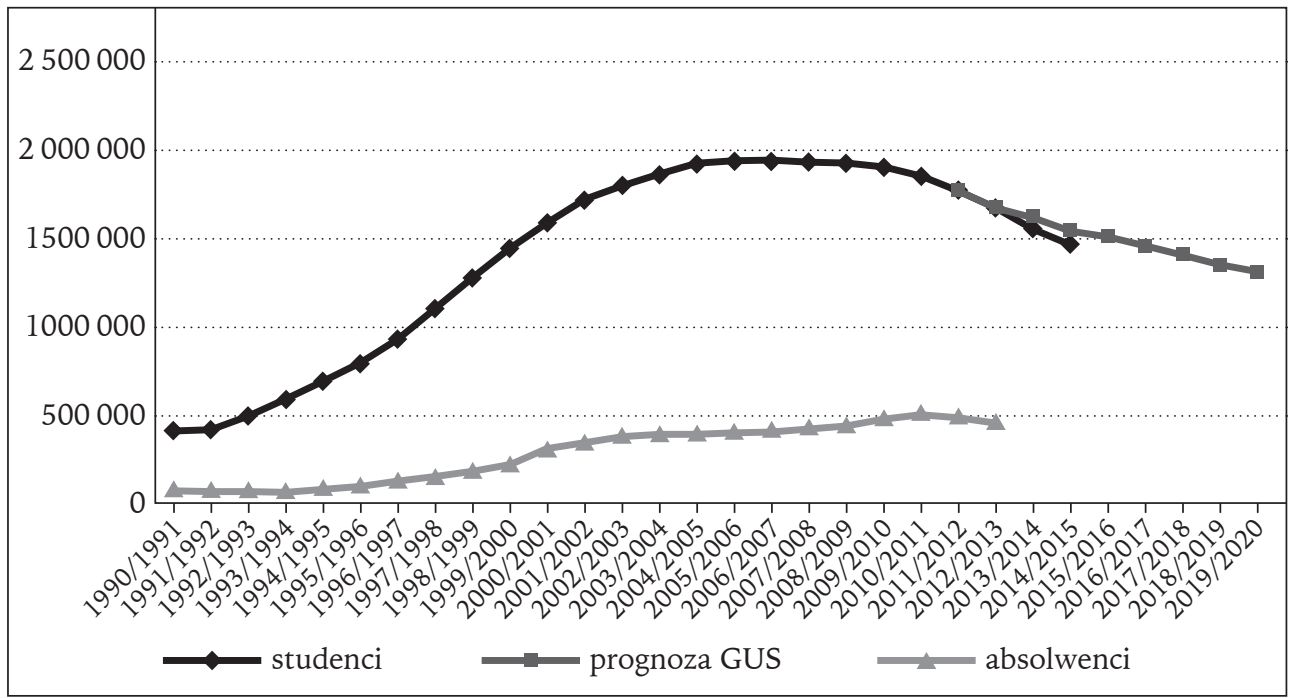

Źródło danych: Szkolnictwo wyższe w Polsce, raport GUS z 2013 roku (https://www.nauka.gov.pl/g2/ oryginal/2013_07/0695136d37bd577c8ab03acc5c59a1f6.pdf).

lacji do mieszkańców jest najwyższy w Polsce, potencjał ekonomiczny nie jest jednak równie wysoki ${ }^{4}$. Liczba studentów nie jest tutaj świadectwem sukcesu ekonomicznego regionu (czy też największego ośrodka: Lublina), ale innych tendencji związanych na przykład z mobilnością ${ }^{5}$.

Wysokie liczebności studentów notujemy w takich miastach jak Warszawa, Wrocław, Kraków czy Poznań, pełniących rolę regionalnych centrów akademickich ${ }^{6}$.

\section{OBECNOŚĆ STUDENTÓW A „STUDENTYFIKACJA”}

Znacząca obecność studentów w konkretnym kontekście przestrzennym jest postrzegana jako wskaźnik przemian miasta, często utożsamianych z od-

Stan, ruch naturalny $i$ wędrówkowy ludności $w$ województwie lubelskim $w 2014$ roku, raport $\mathrm{z}$ maja 2015).

${ }^{4}$ Zob. Szkolnictwo wyższe w Polsce, raport GUS z 2013 roku, wykres 2, s. 9.

${ }^{5}$ Można zapewne zasugerować, że następuje proces „wysysania” bądź drenażu, co sugeruje, by konsekwencje umasowienia studiowania ujmować $\mathrm{w}$ kontekście ponadregionalnym oraz brać pod uwagę znacznie szerszy zakres motywów, niż oferują typowe analizy wiążące obecność instytucji akademickich z zapotrzebowaniem lokalnego rynku pracy.

${ }^{6}$ Fakt ten jest znaczący ze względu na rosnące w ciągu ostatnich dziesięciu lat oddziaływanie mniej lub bardziej masowego podejmowania pracy przez studentów jeszcze w czasie studiów. 
Współczynnik skolaryzacji netto* (w \%)

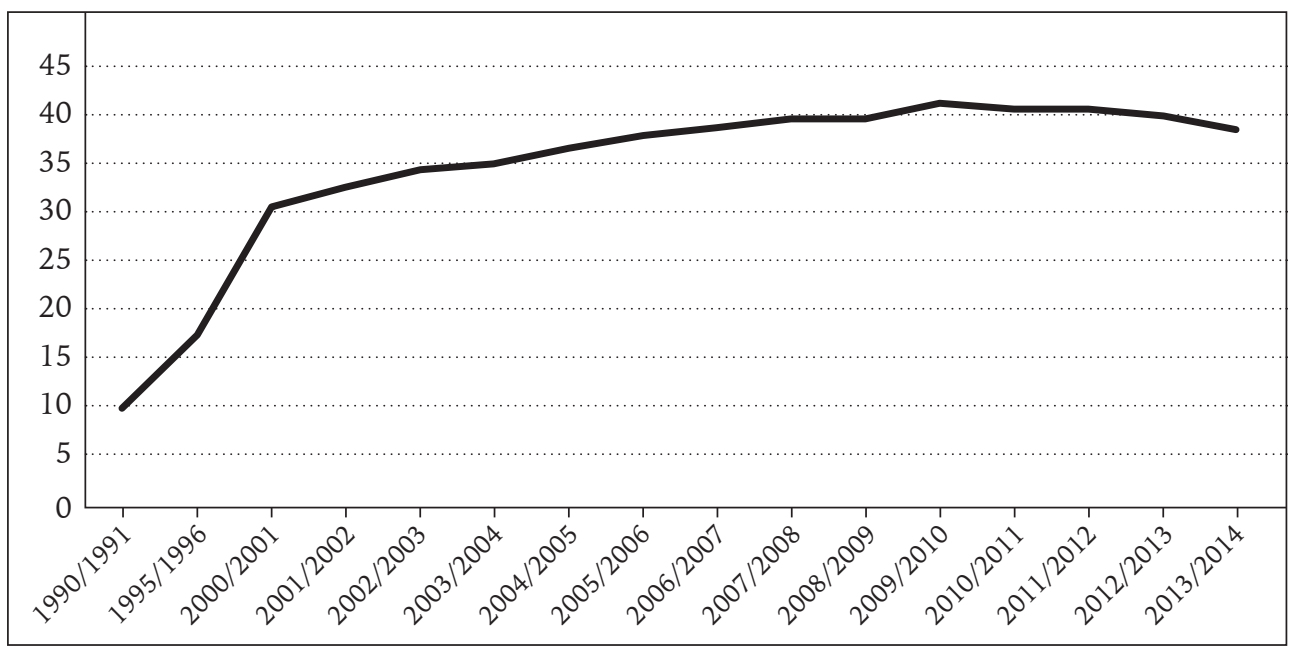

Źródło danych: Szkoty wyższe... (http://stat.gov.pl/files/gfx/portalinformacyjny/pl/defaultaktualnosci/5488/2/10/1/szkoly_wyzsze_i_ich_finanse_w_2013_r..pdf).

*Współczynnik skolaryzacji netto to stosunek liczby osób uczących się w wieku kształcenia na danym poziomie do całej populacji osób będących w wieku przypisanym temu poziomowi.

działywaniem klasy średniej i z tzw. gentryfikacją (Smith 2005). Określenie to zawiera cząstkę gentry, czyli w języku angielskim osoby dobrze urodzone, i oznacza zmianę użytkowników miasta, które pod wpływem procesów rynkowych staje się domeną osób o średnim i wyższym statusie materialnym. Konkretniej zaś - chodzi o przemiany miasta w kierunku nowej jego formy: miasta postindustrialnego (bądź usługowego), z nowymi kategoriami użytkowników lub zmienioną proporcją poszczególnych grup względem całości.

Pojęcie studentyfikacji weszło do języka nauk społecznych na początku nowego millenium (zob. Smith 2005; Smith, Holt 2007; Smith, Hubbard 2014), co wiązane jest ze wskazanymi już przemianami miast. Pierwotnie oznaczało proces powstawania „studenckich gett”, czyli przestrzennej koncentracji studentów szkolnictwa wyższego w wydzielonych enklawach miasteczek uniwersyteckich ze wszelkimi konsekwencjami tendencji do homogenizacji społecznej: jak tworzenie się subkultur i groźnej dla społecznej integracji dominacji jednej kategorii wiekowej czy społecznej oraz proces wtórnego utowarowienia za sprawą właścicieli-inwestorów lub firm deweloperskich zajmujących się dostarczaniem mieszkań studentom (Smith 2005, s. 74).

Innymi słowy: najpierw studenci jako konsumenci-nabywcy wspierali politykę inwestycyjną uniwersytetów, poprzez specyfikę swojej masowej obecności zaczęli dominować na określonych obszarach, następnie po fazie urynkowienia 
relacji społecznych (typowej dla dziesięciolecia następującego po dekadzie lat osiemdziesiątych XX wieku) stali się skuteczną konkurencją dla dotychczasowych użytkowników, modyfikując strukturę społeczną mieszkańców. W tym przypadku „wypychając” innych najemców (w pewnym zakresie również właścicieli) z rynku mieszkaniowego (oczywiście tam, gdzie uzasadniała to racjonalność zamieszkania w bliskości kampusu lub łatwość dojazdu do budynków uniwersyteckich). Co ciekawe, nie chodziło tutaj po prostu o wymianę mieszkańców, ale o „wymianę” na najemców skłonnych mieszkać w warunkach większego zgęszczenia i znacznie bardziej elastycznego najmu. Było to zatem zjawisko, które można określić mianem quasi-gentryfikacji lub fenomenu towarzyszącego tendencjom gentryfikcyjnym (Fabula, Horváth, Boros, Kovács 2015), pojmowanym jako urynkowienie zamieszkania, dotychczas częściej pozostającego (przynajmniej w jakimś zakresie) w domenie etatystycznej regulacji czy ochrony ze strony państwa ${ }^{7}$. Ujęcie zaproponowane przez Darena Smitha najwyraźniej nie zawiera do końca klarownej eksplikacji genezy i wskaźnikowego sensu pojęcia, wpisanych choćby w historyczne przesunięcie sektorowego usytuowania siły roboczej: $z$ przemysłu do usług; z pozycji robotniczych do pozycji pracowników najemnych zatrudnionych w sektorze usług (zob. dobrze znane późniejsze niż Kwestia miejska analizy Manuela Castellsa, ale również znacznie wcześniejsze opracowania historyzujących ekonomistów, zob. np. Urquhart 1984); wreszcie od klasy (proletariatu) do „paraklasy” kognitariatu (Jencks 1986). Tym bardziej nie uwzględnia zmiany mentalnej, jaka towarzyszyła umasowieniu studiowania w Europie Środkowej i Wschodniej ${ }^{8}$. Poszerzenie kontekstu interpretacyjnego pozwala spojrzeć na studentyfikację na nowo.

Proponuję, aby pojęcie studentyfikacji służyło $z$ jednej strony odpowiedzi na pytania o uwarunkowania umasowienia studiowania, $z$ drugiej - dalej idącym, krytycznym, interpretacjom konsekwencji masowej obecności studentów w mieście, opisywanej w kategoriach kauzalnych, $z$ analitycznym wydzieleniem tego obszaru z szerszej puli czynników decydujących o późnonowoczesnej ewolucji miasta.

Daren Smith, zmierzając w kierunku poszerzenia pola badawczego poza zagadnienia rynku nieruchomości, opisywał kilka wymiarów studentyfikacji ${ }^{9}$. Można je sprowadzić do trzech aspektów:

7 Pojęcie studentyfikacji nieprzypadkowo sąsiaduje tutaj z pojęciem gentryfikacji opisującym wymianę użytkowników przestrzeni współczesnych miast według kryterium siły nabywczej. Nie chodzi tu jednak o gentryfikację w pełnym tego słowa znaczeniu, ale raczej na zmianę typu naj$\mathrm{mu}$, przekształcenie stosunków własnościowych i zmianę parametrów społecznych dominujących użytkowników przestrzeni miast.

${ }^{8}$ Nawiązuję tu do języka tzw. teorii zależności czy teorii postkolonialnej w istocie będącej odbiciem podobnych procesów, tyle że w odmiennych gospodarczo warunkach "systemowych peryferiów".

${ }^{9}$ Były to następujące wymiary: (1) ekonomiczny, wpływ siły nabywczej studentów na rynek nieruchomości (w kontekście przywołanego już zjawiska gentryfikacji); (2) społeczny (wymiana ludności o względnie stabilnej sytuacji życiowej i stabilnym stylu życia na grupę społeczną cha- 
— związku ze studentyfikacją ewolucji procesu wytwarzania wiedzy, w którym edukacja staje się elementem komodyfikacji, a studiowanie jest „dokonywaniem zakupu" rzadkiego dobra podlegającego rynkowej wycenie;

— zmiany idei miejskości w obliczu fenomenu studentyfikacji, w sytuacji wzrostu znaczenia tzw. użytkowników zewnętrznych, czyli grup, których status jest przejściowy czy czasowy, a charakter oddziaływania realizuje się głównie poprzez sektor usługowy;

- selektywnego uealstycznienia rynku pracy, którego konsekwencje opisywane są w literaturze przy użyciu pojęć dualizmu rynku pracy czy na przykładzie prekaryzacji ${ }^{10}$.

Wymienione aspekty zjawiska studentyfikacji — poza oczywistością globalizacyjnej presji (w regionalnych warunkach: europeizacji) wskazują na realizację wyobrażenia na temat urynkowienia jako narzędzia rozwiązywania problemów, przy czym tzw. nowa klasa średnia, utożsamiana z merytokracją, staje się grupą odniesienia (nawet gdy jej istnienie jako klasy jest kwestionowane; zob. Gdula, Sadura 2012). Student jest tutaj zarówno k on sumente m, „czynnikiem" zwiększenia podaży pracy (w ramach określonego rynku), jak i za sobem siły roboczej, który może zasilić po okresie studiów późnonowoczesne miasto (zgodnie $z$ profilem uzyskanych kwalifikacji rzecz jasna, jeśli owe kwalifikacje są na lokalnym rynku poszukiwane). Chcąc umożliwić przejście od konceptualizacji do operacjonalizacji pojęcia studentyfikacji, wypada rozpocząć od koncepcji roli studenta uniwersytetu.

\section{DEFINICJA STUDENTA A KOMODYFIKACJA WIEDZY I STUDENTYFIKACJA}

W historycznej już refleksji Floriana Znanieckiego możemy się doszukać co najmniej kilku ujęć roli studenta uniwersytetu: od perspektywy działaniowej poprzez powiązanie z rolą społeczną jako „uporządkowanym systemem działań" aż do zdefiniowania studenta jako: „pewnego rodzaju «wyobrażenia», podzielanego przez tych, którzy wchodzą z nim kontakt" (Znaniecki 1997, s. 39). Perspektywa teoretyczna jest zatem szeroka, zawiera zarówno pewne wymogi

rakteryzującą się labilnością), czyli społeczne konsekwencje obecności studentów w przestrzeni miasta; (3) kulturowy (dominacja kultury młodych ludzi znamionująca ewolucję miejskiego stylu życia); (4) fizyczny (specyfika przestrzeni kształtowanej ze względu na potrzeby i oczekiwania studentów) - obraz fizyczności miasta „zestudentyfikwanego” (zob. Smith 2005).

10 Chodzi o uwypuklenie przekształceń współczesnego kapitalizmu w relacji do nowoczesnego państwa, w którym stosunki rynkowe wywierają presję, by redukować zakresy państwowej interwencji (w imię podtrzymania konkurencyjności). Przy czym państwo ciągle pozostaje depozytariuszem części osiągnięć europejskiego welfare state (w tym choćby prawa do bezpłatnego szkolnictwa i bezpłatnych studiów oraz systemu stypendiów), „rynek” zaś prywatyzuje ryzyko związane $z$ decyzjami edukacyjnymi (zob. tezy Ulricha Becka $z$ lat osiemdziesiątych XX wieku; Beck 2002). Globalnej kumulacji własności prywatnej (zob. Piketty 2015) towarzyszą tendencje do prekaryzacji (zob. Standing 2014), a wzrostowi znaczenia kompetencji i wiedzy - radykalne uelastycznienie rynku pracy (coraz częściej o dualnym charakterze; zob. Lallement 2012). 
formalne pozwalające zidentyfikować kategorię osób w kontekście wąsko rozumianego ładu instytucjonalnego (np. na podstawie posiadania odpowiedniej legitymacji świadczącej o uzyskaniu pewnych praw i uczestnictwie w zajęciach organizowanych przez szkołę wyższą), jak i wyobrażenie na ich temat, co ma charakter kulturowego bądź społecznego konstruktu świadomościowego i jest źródłem działań innych (choćby budowania oferty usługowej kierowanej do zbiorowości na podstawie antycypowania potrzeb i stylu życia). Rolę studenta wypada zatem przeanalizować per se, ale również z punktu widzenia konsekwencji, jakie studenci wprowadzają do szerszych relacji systemowych. Jest to istotne tym bardziej, w im wyższym stopniu cechy specyficznej roli społecznej (studenta) wpisane w specyfikę obecności uniwersytetów (szkół wyższych), a także ich społeczny odbiór, zyskują na znaczeniu i stają się składnikiem procesów masowych, z czym dotychczas (w Polsce zapewne do połowy pierwszego dziesięciolecia XXI wieku) nie mieliśmy do czynienia na podobną skalę.

Można zadać pytanie, dlaczego akurat przemiany wiedzy, a co za tym idzie szkolnictwa wyższego jako instytucji mają być przedmiotem kauzalnej analizy współczesnych przemian inspirujących studentyfikację? Może być tak ponieważ: po pierwsze, zarówno zagadnienie znaczenia wiedzy, jak i kondycja szkolnictwa pozostawały i pozostają $\mathrm{w}$ związku ze słabnięciem państwa narodowego (zob. Bauman 1999; Kwiek 2006, s. 58 i nast.), a jednocześnie mimo narastania zjawisk globalizacyjnych aktywna rola państwa w zakresie finansowania szkolnictwa wyższego (typowa dla kontynentalnej Europy) nie uległa radykalnej zmianie ${ }^{11}$. Mamy zatem do czynienia jednocześnie $z$ publicznym subsydiowaniem sektora edukacyjnego oraz zjawiskiem komodyfikacji wiedzy (zob. Fleissner 2009; Radder 2010). Proces ten sprawił, iż wiedza wtłoczona w proces edukacyjny stała się przedmiotem obrotu i była (jest) traktowana jak publicznie subsydiowany „towar” ${ }^{12}$. Co warto podkreślić, towar dość specyficzny, można go, niemal niezmieniony, wielokrotnie sprzedawać, nie angażując się $\mathrm{w}$ poważniejszym stopniu $\mathrm{w}$ jego wytwarzanie. $\mathrm{Z}$ tego punktu widzenia edukacja uniwersytecka „[...] nie jest już postrzegana głównie jako droga zdobywania społecznie wartościowej wiedzy, ale proces $\mathrm{w}$ ramach którego wartość [wiedzy] jest determinowana poprzez to, ile przynosi konkretnych korzyści studentom-konsumentom. $Z$ tego powodu pojęcie komodyfikacji opisuje zadania dla zarządzających [wiedzą] i proces produkcyjny prowadzący do podwyższenia

${ }^{11}$ Dostępne dane wskazują, że wydatki na jednego studenta dla Polski w roku 2009 wynosiły średnio 7776 dol., podczas gdy podobny wskaźnik dla krajów OECD to 13728 dol. Zob. Wydatki na szkolnictwo wyższe w krajach OECD. Raport firmy Sedlak\&Sedlak (http://rynekpracy.pl/ artykul.php/typ.1/kategoria_glowna.136/wpis.680 [kwiecień 2016]).

12 Komodyfikację wiedzy można uznać za pojęcie paralelne do komercjalizacji, gdyż „uzyskiwanie profitów przez instytucje akademickie następuje poprzez sprzedaż ekspertyz zatrudnionych badaczy i rezultatów ich studiów", co oznacza wzrost ekonomicznego znaczenia podobnych instytucji wpisujących się we współczesne tendencje rozwojowe (zob. Radder 2010, s. 4). 
jakości produktów edukacyjnych na podstawie poczucia satysfakcji studentów-konsumentów" (Kauppinen 2014, s. 394).

Ponadto „sprzedaż” wiedzy (procesu edukacyjnego) stała się działalnością gospodarczą na skalę ponadregionalna i ponadnarodową, co jest powiązane $\mathrm{z}$ narastaniem mobilności $\mathrm{w}$ obrębie poszczególnych państw i w perspektywie globalnej. W praktyce oznacza to, że to nie „my” docieramy z naszą ofertą do konsumentów (poprzez książki, czasopisma itp.), lecz studenci-konsumenci przemieszczają się do nas według logiki: od miejsc-ośrodków o niższym statusie akademickim do tych o wyższym (co gwarantuje bardziej skuteczne utowarowienie) ${ }^{13}$. Wspomniana mobilność (przemieszczanie się „za wiedzą” i kompetencjami) może zatem osiągać znaczące rozmiary. Wydaje się, że jej znaczenie dla miast rośnie wraz ze spadkiem potencjału demograficznego obszarów regionalnych wokół głównych ośrodków akademickich i ogólniejszymi zjawiskami starzenia się społeczeństw.

Przejdźmy do liczb dotyczących środkowej Europy i Polski: w 2012 roku w naszym kraju było blisko 36 tys. zagranicznych studentów. W kolejnych latach liczba ta rosła, była zatem znacząca. Innym aspektem tego samego procesu był intensywny rozwój instytucji szkolnictwa niepublicznego, stanowiących konkurencję dla szkolnictwa publicznego. Proces rozrostu tego sektora największą intensywność osiągnął w latach 2009-2010 (powstało najwięcej szkół), rok wcześniej dało się zanotować największą liczbę studentów. Największa liczba absolwentów takich szkół trafiła na rynek pracy w latach 2011/2012.

O dynamice strukturalnej sektora (znamionującej działanie mechanizmów rynkowych w warunkach niżu demograficznego) świadczy rozwój, a następnie od początku drugiego dziesięciolecia nowego millenium konsolidacja niepublicznego szkolnictwa wyższego, przy znacząco spadającej liczbie studentów i stabilnej liczbie kilkunastu tysięcy absolwentów opuszczających mury uczelni (zob. wykres 3). Przykład polski nie wydaje się szczególny na tle doświadczeń europejskich.

Prywatyzację i komodyfikowanie wiedzy, typowe dla „kapitalizmu wiedzy”, oparte na zasadzie tzw. własności intelektualnej, najlepiej przedstawić na przy-

13 Choć wiedza jako taka wydaje się dostępna wszystkim w zakresie porównywalnym (np. za pośrednictwem systemu szkolnictwa, dostępu do bibliotek i internetu), to bardziej wyspecjalizowane jej aspekty (te, które gwarantują wysoką pozycję i „wysoki zwrot” z inwestycji edukacyjnej) można kupić jedynie w określonych miejscach. Po „odprzestrzennieniu” wiedzy, związanym z rozwojem technologii sieciowej lat dziewięćdziesiątych XX wieku, nastąpiło zatem jej „zakorzenienie” oparte na naukowej specjalizacji, istniejących regulacjach dotyczących prawa własności intelektualnej, zapośredniczonych przez struktury korporacyjne, mające po części charakter sieciowy, po części hierarchiczny. Nieco modyfikuje ten obraz rozwijający się tryb kształcenia on-line (tzw. e-lerning), na razie nie stanowi on jednak konkurencji dla „zakorzenionego” trybu kształcenia. Stosunek społeczny „nauczyciel-uczeń”, typowy dla kształcenia uniwersyteckiego, trudno zresztą skutecznie „odprzestrzennić" bez utraty wiarygodności jako dostarczyciel wysoko cenionych kompetencji. 
Wykres 3

Liczba studentów szkół prywatnych (w tys.), liczba absolwentów wyższych szkół niepublicznych (w tys.) oraz liczba szkół wyższych w Polsce w latach 1997/1998-2013/2014

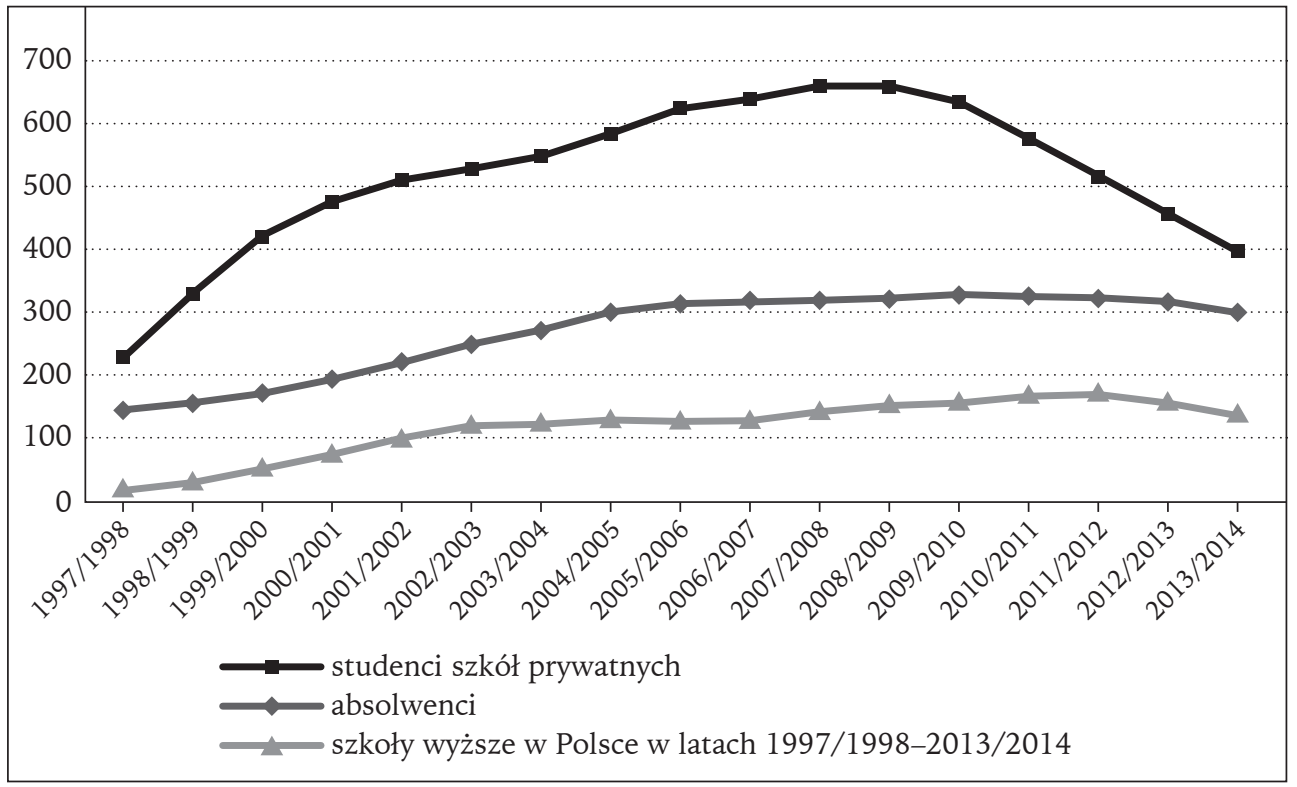

Źródło danych: Szkoły wyższe i ich finanse 2013. Raport GUS (http://stat.gov.pl/obszary-tematyczne/ edukacja/edukacja/szkoly-wyzsze-i-ich-finanse-w-2013-r-,2,10.html).

kładzie nauk społecznych, historycznie pełniących rolę wiedzy „społecznie wartościowej”, ważnej dla polityki nowoczesnego państwa narodowego. Według wizji Immanuela Wallersteina (2004, s. 171 i nast.) nauki społeczne pozostają $z$ jednej strony pochodną rozwoju gospodarki rynkowej (kapitalizmu), $z$ drugiej emanacją „optymistycznego liberalizmu”. Oferują zarazem dobrobyt wszystkim, niezależnie od statusu społecznego i promują indywidualistyczne pojmowanie sukcesu i sprawstwo (dostępne „zwycięzcom”). Ta niespójność sprawia, że różnorodność staje się podstawowym wyzwaniem, a wybór kluczowym momentem biografii, niezależnie od uniwersalnej oferty (w wielu przypadkach pozostającej jedynie obietnicą) kierowanej do wszystkich. Co ważne, dystrybucja i charakter wiedzy pozostają w związku z władzą, co nadaje polityce znamiona racjonalności, a w polskich warunkach do 1989 roku oznaczało silne związanie nauk społecznych z polityką etatystycznego państwa (które samo wytwarzało „popyt” na wiedzę, a także jego granice). Po roku 1989 wiedza nie zmieniła swojej roli, co świetnie ilustruje zaangażowanie wielu socjologów w promowanie transformacji systemowej (jako procesu przejścia od dysfunkcjonalności realnego socjalizmu do funkcjonalności realnego kapitalizmu; zob. Kolasa-Nowak 2011). Jednocześnie ta sama wiedza podlegała komodyfikacji, co 
można obserwować w szerszym europejskim kontekście na podstawie kondycji uniwersytetów, które wewnętrznie pozostają strukturami demokratycznymi (poziomymi), z perspektywy zewnętrznej zaś są „nie tylko usługodawcami [servants] świadczącymi usługi na potrzeby rynku. Są [również] aktywnymi graczami, poprzez sprzedaż pakietów dóbr takich jak patenty" (Kauppinen 2014, s. 394).

Pozycja studenta nauk społecznych jest (była) o tyle szczególna, o ile jest (była) wypadkową wartościowania zasobu jego wiedzy, łączącego zarówno wątki aplikacyjne (przykładem mogą być $z$ jednej strony praca socjalna, $z$ drugiej marketing) $z$ wątkami doktrynalnymi (wizją transformacji jako liniowego procesu, dobrze działającej gospodarki kapitalistycznej czy społeczeństwa klasy średniej), jak i wątki radykalne pozostające rezerwuarem zmiennej dynamiki ruchów społecznych. Każde z pól wytwarza(ło) wyodrębniające się obszary „podaży” wiedzy, podlegające następnie urynkowieniu.

Rodziło to uogólniające, optymistyczne wnioski dotyczące przyszłości:

„[...] przez najbliższe 15 lat - dowodzą w swojej ekspertyzie autorzy raportu Wptyw sektora szkolnictwa wyższego na Produkt Krajowy Brutto — inwestowanie w szkolnictwo wyższe będzie przynosić największe publiczne zyski. Po upływie tego czasu, ze względu na zachodzące zmiany demograficzne, Polska zbliży się do optymalnego udziału osób $z$ wyższym wykształceniem $w$ grupie pracujących, a który będzie odpowiadał poziomowi skolaryzacji w tradycyjnej grupie wiekowej studentów (19-24). Wówczas, ze względu na liczbę absolwentów pozostających na rynku pracy, koszty transferów społecznych wyrównają się. To z kolei doprowadzi do sytuacji, kiedy prywatna stopa zwrotu z inwestycji w wyższe wykształcenie zrówna się ze stopą publiczną" (Bugaj i in. 2012).

Nakłady na szkolnictwo wyższe zwrócą się zatem, co z punktu widzenia struktury społecznej będzie oznaczało dalsze upowszechnienie wyższego wykształcenia (nie tylko w młodszych generacjach, co uznano za zjawisko ze wszech miar pozytywne). Rola studenta zaś jest ekonomicznie opłacalna, zarówno ze względu na indywidualne korzyści (jeżeli pozyskane kwalifikacje dadzą się „sprzedać” na rynku), jak i ze względu na korzyści systemowe, których przesłanki są jednak silnie obciążone określonym obrazem kapitalizmu, obowiązującym w danej jego fazie (zob. Gołębiowski 2007; Snowdon 2006). Co ciekawe, sam proces komodyfikacji wiedzy uzasadniał potrzebę urynkowienia systemu kształcenia jako narzędzia rozwiązywania problemów (choćby „nadprodukcji" osób o wysokim kapitale edukacyjnym). To jest zapewne kolejne rozumienie studentyfikacji - tym razem jako procesu pochodnego komodyfikacji wiedzy, na poziomie ewolucji systemu społecznego i budowy potencjału konkurencyjności: postprzemysłowego miasta $\mathrm{w}$ fazie postindustrialnego kapitalizmu.

Warto podkreślić, że niezależnie od fenomenu dowartościowania wiedzy (jako towaru —źródła zysków) studentyfikacja stała się czynnikiem dynamizującym lokalne rynki, uruchamiając niejako wtórnie procesy inwestycyjne. Na- 
silenie zmian przestrzennych (i poziom angażowanych środków) w polskich warunkach widoczne jest choćby w poprawie infrastruktury edukacyjnej (nowe budynki dydaktyczne czy wzrost infrastruktury socjalnej przeznaczonej dla studentów). Analogiczne spostrzeżenia da się sformułować na podstawie analizy danych brytyjskich i amerykańskich (zob. Bures, Cain 2008). O badawczym dostrzeżeniu tych zjawisk na rodzimym gruncie świadczy rozwój refleksji na temat „miastotwórczej funkcji uniwersytetu”. Próbuje się ujmować proces wzrostu znaczenia organizacji edukacyjnych syntetycznie i przestrzennie zarazem ${ }^{14}$.

Co ważne, istotny jest wspomniany aspekt polityki redystrybucyjnej państwa narodowego, która obniża koszty ponoszone przez „konsumenta wiedzy” i czyni możliwym umasowienie kształcenia na poziomie wyższym ${ }^{15}$. Formy transferów publicznych za pośrednictwem uniwersytetów - i szerzej szkół wyższych - wpływają zaś na kondycję miast. Rodzi to potrzebę sformułowania dwóch hipotez jako podstawy konstrukcji teoretycznej zjawiska studentyfikacji: (1) o istnieniu wprost proporcjonalnego $z \mathrm{wiązku} \mathrm{między} \mathrm{komo-}$ dyfikacją wiedzy a natężeniem studentyfikacji oraz (2) o istnieniu związku między natężeniem studentyfikacji a polityką publicznego dofinansowywania szkolnictwa wyższego, typową dla gospodarek Europy kontynentalnej ${ }^{16}$. Szczegółowe dane dotyczące wspomnianych transferów do konkretnych miast wymagają analiz, którymi dotychczas nie dysponujemy. Faktem jest jednak, że w konsekwencji deindustrializacji z lat dziewięćdziesiątych XX wieku uniwersytety pozostają znaczącymi (czasami największymi) pracodawcami we współczesnych miastach ${ }^{17}$. Wywołuje to pytania dotyczące ewolucji „miejskości”, wynikającej z presji nowych masowych typów praktyk związanych z „wytwarzaniem” i „obrotem” wiedzą oraz nowych grup masowych konsumentów (usługobiorców).

14 „Miastotwórcza rola uniwersytetów” — pod takim tytułem odbyła się na Uniwersytecie Ekonomicznym w Poznaniu konferencja, w której założeniach napisano: „Rolą uczelni wyższych jest generowanie nowych wartości, a wyzwaniem staje się niewątpliwie współpraca $z$ otoczeniem, w której szczególną rolę odgrywają partnerskie relacje z samorządem miasta i regionu", zob. materiał zamieszczony w Poznańskim Biuletynie Miejskim na stronie Urzędu Miasta Poznania (http://www.poznan.pl/mim/bm/news/wydarzenia-poznanskie,c, 10/miastotworcza-rolauniwersytetow,91159.html [marzec 2016]).

${ }^{15}$ Zob. Wydatki na szkolnictwo wyższe w krajach OECD. Raport firmy Sedlak\&Sedlak.

16 Skądinąd wskaźniki skolaryzacji szczególnie wysokie są, zapewne dość paradoksalnie, w społeczeństwach postkomunistycznych, gdzie na szkolnictwo wydatkuje się środki nominalnie znacząco niższe niż w gospodarkach tzw. rozwiniętego Zachodu (por. dane Eurostatu oraz przywołane dane $z$ raportu firmy Selak\&Sedlak). Sugeruje to, że zjawisko komodyfikacji i wielkość transferów społecznych (związanych z finansowaniem szkolnictwa wyższego) wypada tam traktować odrębnie, ze świadomością występowania zjawiska studentyfikacji.

${ }_{17}$ Nauczycieli akademickich zatrudnionych na 18 uniwersytetach jest ponad 30 tys., studentów tych uczelni jest ponad 500 tys. (zob. dokument z 2010 roku: Analiza zasobów kadrowych w uczelniach na poszczególnych kierunkach $i$ wypracowanie zasad etatyzacji, s. 34, tab. 3 (https://www.nauka. gov.pl/g2/oryginal/2013_05/215fd69485a3e2e4ffecbe41cf9183d6.pdf [kwiecień 2016]). 


\section{ZMIANY FORMY MIEJSKOŚCI A STUDENTYFIKACJA — PRZYKŁAD ZACHOWAŃ KONSUMPCYJNYCH POZNAŃSKICH STUDENTÓW}

Studentyfikacja może wiązać się z próbami rearanżacji przestrzeni podporządkowanymi nowemu masowemu „użytkownikowi”, charakteryzującemu się określonym stylem i preferencjami dotyczącymi sfery konsumpcji, na przykład również konsumpcji kultury ${ }^{18}$. Przykładem opracowania, w którym poddaje się analizie między innymi zachowania konsumenckie studentów jest monografia: Poznański ośrodek akademicki. Zachowania konsumenckie studentów (Gaczek, Kaczmarek 2015) ${ }^{19}$. Opublikowane w nim dane potraktuję jako ilustrację empirycznego podejścia do tytułowego zagadnienia. Zachowanie konsumenckie są tam ujmowane $\mathrm{w}$ sposób odpowiadający zaproponowanemu przeze mnie rozumieniu roli studenta, w odniesieniu do „wzajemnych związków pomiędzy wielkościami (czynnikami) wpływającymi na zachowania i rezultatami tych zachowań" (Gaczek, Kaczmarek 2015, s. 72).

Autorzy dzielą wspomniane czynniki na indywidualne (obejmujące między innymi indywidualne preferencje), interpersonalne (dotyczące specyfiki grupy uczestnictwa, subkultury itp.) oraz zewnętrzne (czynniki geograficzne, ekonomiczne, prawne, technologiczne) (Gaczek, Kaczmarek 2015, s. 73).

Pierwszy obszar refleksji opartych na wynikach ankiety dotyczył form zamieszkania i pobytu studentów. Na podstawie analizy statystycznej badacze ustalili dominację zamieszkania tymczasowego (zapewne w większości najmu: $60,2 \%)$. W większości były to mieszkania studenckie $(41,8 \%)$, stancje $(28,5 \%)$, rzadziej własne mieszkania (11,7\%). Miejsca w akademikach zajmowało ok. $1 / 6$ studentów $(16,8 \%)^{20}$. Co warto podkreślić $-14,8 \%$ studentów dojeżdża do Poznania (nie korzysta z zamieszkania na miejscu).

18 Potraktowanie z osobna sfery kultury wydaje się istotne ze względu na jej wartość, którą można określić jako pozainstytucjonalną (por. definicję uczestnictwa w kulturze Marka Krajewskiego; 2013). Wynika to z obserwacji wielu badaczy kultury współczesnej, którzy dostrzegają, że „pytanie o «uczestnictwo w kulturze» stało się mniej produktywne analitycznie i politycznie niż pytania o formy współpracy w produkcji treści kulturowych, kompetencje estetyczne, hermeneutyczne czy społeczne związane z poruszaniem się w zalewie informacji, obrazów i narracji, czy tworzenie warunków dla powstawania sieciowych zbiorowości wokół praktyk kulturowych lub tekstów kultury" (Filiciak i in. 2010, s. 8).

19 Przedstawione w tym opracowaniu badanie zrealizowano na podstawie wystandaryzowanej ankiety audytoryjnej, a zatem narzędzia o charakterze nieprobabilistycznym, przy założeniu doboru badanych odwzorowującego specyfikę populacji studentów poznańskich (wariant doboru kwotowego). Co warto podkreślić, badanie z 2015 roku było poszerzoną kontynuacją badania zrealizowanego dziesięć lat wcześniej, w 2005 roku, przy użyciu podobnych narzędzi, czyli ankiety audytoryjnej. W badaniu wzięło wtedy udział ponad 800 studentów

${ }^{20}$ Interesujące, że typ uczelni pozostaje w związku z rodzajem zamieszkania. Częściej korzystają z mieszkań studenckich studenci Uniwersytetu Ekonomicznego, ze stancji studenci Uniwersytetu im. Adama Mickiewicza, z akademika zaś studenci Uniwersytetu Przyrodniczego. Przyczyna tego nieoczywistego związku wydaje się związana z liczbą miejsc oferowanych przez uczelnie (Gaczek, Kaczmarek 2015, s. 84). 
Jeśli chodzi o deklaracje dotyczące miejsca zamieszkania, to dostrzegalna była tendencja do wiązania go z lokalizacją budynków uniwersyteckich - najwyższe usytuowanie w rankingu kryteriów wyboru zajęło „miejsce zamieszkania w pobliżu uczelni" $(49,8 \%)$. Na drugim miejscu znalazła się atrakcyjna cena wynajmu $(48,8 \%)$, co wskazuje na równie duże znaczenie socjalnych przesłanek wyboru. Poziom wydatków mieszkaniowych studentów istotnie różnicuje typ uczelni, co pośrednio ilustruje również poziom komodyfikacji wiedzy dominującej na poszczególnych uczelniach. Przy czym różnice wydatków kształtują się średnio od 550 do $600 \mathrm{zł}$.

Liczba studentów mieszkających tymczasowo szacowana była na 34 tys. (por. Gaczek, Kaczmarek 2015, s. 91, tab. 16), pozwala to szacować poziom transferów finansowych kierowanych do wynajmujących (stancje lub mieszkania studenckie) na sumę blisko 15 mln zł miesięcznie. Kwota ta zapewne bezpośrednio oddziałuje na gospodarkę miasta (najczęściej obszaru centrum), oczywiście, w sposób rozproszony przestrzennie i nie jest to jedyny czynnik uwarunkowany studentyfikacją.

Innym ważnym elementem oddziaływania na miasto masowej obecności studentów mogą być kwestie transportu. Jak się okazuje, studenci w zdecydowanej większości korzystali z komunikacji publicznej (72,7\%), z samochodu zaś jedynie 7,2\%.

Robiąc bieżące zakupy (codziennie lub kilka razy w tygodniu) studenci najczęściej wybierali małe sklepy lub osiedlowe supermarkety (Gaczek, Kaczmarek 2015, s. 102, tab. 18). Kryterium wyboru, podobnie jak w przypadku miejsca zamieszkania, było podporządkowane, tym razem w odwrotnej kolejności: wysokości cen i bliskości miejsca zamieszkania. Wbrew stereotypowi studenci w przeważającej większości spożywali posiłki w domu (92,9\%). Składa się to na obraz zdecydowanie „zrównoważonego stylu życia” podporządkowanego funkcjonalności przestrzennej i kryterium niskich kosztów. Poziom wydatków miesięcznych na wyżywienie szacunkowo był zbliżony w grupach studentów różnych uczelni - wynosiły one od około 300 do 360 zł. Co ciekawe, najwięcej wydawali na wyżywienie studenci Uniwersytetu Ekonomicznego, podobnie zresztą najczęściej „jedli oni na mieście” (Gaczek, Kaczmarek 2015, s. 108). Jak szacują autorzy, przeciętna kwota przychodów uzyskiwanych w mieście z tytułu wyżywienia studentów wynosiła ok. $11 \mathrm{mln}$ zł miesięcznie.

Aby obraz oddziaływania rynkowego studentów był pełny, należy do wskazanych kwot dodać środki wydawane na edukację (w tym choćby na odpłatne kursy językowe) oraz koszty spędzania czasu wolnego i uczestnictwa w kulturze. Warto odnotować, że dominującym sposobem spędzania czasu wolnego (na podstawie deklaracji) było korzystanie $z$ pubów (około 1/4 wskazań kilka razy w tygodniu i 2-3 razy w tygodniu), poza tym siłownia, aeorobik i bilard. $Z$ kolei najczęstszą formą korzystania $z$ instytucji kultury było uczęszczanie do kina, a następnie do teatru. Gdy analizujemy miesięczne wydatki na wskazaną sferę, to dominuje pub ( $65 \mathrm{zł} \mathrm{miesięcznie),} \mathrm{dalej} \mathrm{kino} \mathrm{(31} \mathrm{zł)} \mathrm{i} \mathrm{basen} \mathrm{(25} \mathrm{zł),} \mathrm{na}$ 
pozostałe propozycje wydawane jest znacznie mniej (Gaczek, Kaczmarek 2015, ryc. 44, s. 127). Daje to sumę (średnią), którą dysponuje przeciętny student 905 zł miesięcznie (Gaczek, Kaczmarek 2015, s 141 i nast.), przy czym także tu największym budżetem dysponowali studenci Uniwersytetu Ekonomicznego (1075 zł miesięcznie).

W rekonstrukcji wyników badania skupiono się na studentach wynajmujących mieszania, założono bowiem, że to oni są najczytelniejszym wskaźnikiem procesu studentyfikacji polskich miast. Oczywiście, wysokie wskaźniki skolaryzacji dotyczą również osób mieszkających na stałe w mieście, wskazane sumy należałoby zatem podwyższyć. Podsumowując, szacowana pula środków wydawanych przez studentów tymczasowo zamieszkujących Poznań to około 33,5 mln zł. Po uwzględnieniu studentów mieszkających w mieście na stałe suma ta wzrasta do około 45 mln zł miesięcznie (Gaczek, Kaczmarek 2015, s. 147, tab. 32). Obraz powinien być jeszcze bogatszy po uwzględnieniu sfery nie dotyczącej bezpośrednio studiowania.

Gdy sięgniemy do sfery obrotu gospodarczego i sfery obiegu informacji, okaże się, że studentyfikacja może oddziaływać zarówno na kształt usług (w tym kultury), jak i na przykład na rynek mieszkań (w tym duży udział w nowych inwestycjach małych mieszkań, tzw. kawalerek), rynek wtórny mieszkań (ceny mieszkań warunkuje oddalenie od kampusów uniwersyteckich) i ceny najmu. Rozwój sektora usług konsumpcyjnych podporządkowany stylowi życia studentów obejmuje zarówno zjawiska pozytywne dla rozwoju ekonomicznego miasta, jak i negatywne. $Z$ jednej strony może prowadzić do zwiększania liczby miejsc takich jak puby, siłownie (wskazywane jako główne pozycje w części studenckich budżetów przeznaczanej na spędzanie wolnego czasu), z drugiej strony może przyczyniać się do podupadania drobnych wyspecjalizowanych sklepów zorientowanych na lokalnych odbiorców (pasmanterii, tzw. warzywniaków itp.). Może zwiększać podaż odpłatnych usług świadczonych przez punkty ksero, bary typu fast food, a także uzasadniać pojawienie się w przestrzeni centrów miast zdigitalizowanych bibliotek pełniących rolę miejsc pracy naukowej, poza dostępem do literatury oferujących dostęp do terminali komputerowych oraz na przykład miejsca spotkań, które na określony czas można wynajmować do tzw. co-working-u ${ }^{21}$.

W pewnym zakresie specyfika zmiany, którą można ilustrować danymi z badania poznańskiego, podobna jest do oddziaływania masowej turystyki, która również eksploruje symboliczne centra miast, łącząc konsumpcję kulturowego dziedzictwa $z$ korzystaniem $z$ usług, nazwijmy je, rozrywkowo-komunikacyjnych. Być może nakładanie się tych zjawisk sprawia, że upadek „starych” i pojawienie się „nowych miejsc” (w okolicach często odwiedzanych) rzadziej postrzegamy jako konsekwencję studentyfikacji niż upowszechnienia turysty-

${ }^{21}$ Podobną tendencję inspirowaną popytem ze strony studentów może ilustrować coraz powszechniejsza w miastach oferta bezpłatnego dostępu do sieci za pomocą technologii wi-fi. 
ki. Przemawia to za traktowaniem studentyfikacji paralelnie do oddziaływania tzw. użytkowników zewnętrznych. Choć obecność studentów w przestrzeni miasta $z$ reguły przekracza ramy krótkiego pobytu, charakteryzuje ją jednocześnie daleko idąca masowość, labilność (w tym niższy poziom konsumenckiej lojalności), skłonność do korzystania z wszelkiego rodzaju usług według kryterium ceny (i poszukiwań w tym zakresie), koncentracja na określonych aspektach życia społecznego ${ }^{22}$. Rodzi to kolejne hipotezy, które można sformułować następująco: (3) istnieje związek u ma sowienia obecności studentów w mieście z kształtem sfery usług, regulowanej według mechanizmów rynkowych, a (4) wskazane zmiany (sfery usług) mają tendencję do pojawiania się $\mathrm{w}$ przestrzeni miasta zgodnie z przestrzennym rozlokowaniem instytucji edukacyjnych, co uruchamia zarówno zjawiska specjalizacyjne, jak i tendencje, które można wiązać z gentryfikacją lub quasi-gentryfikacją.

\section{STUDENTYFIKACJA A RYNEK PRACY}

Zgodnie z ustaleniami badań amerykańskich i brytyjskich (zob. Smith 2005; Smith, Holt 2007; Smith, Hubbard 2014) miejsca zamieszkania studentów częściej znajdują się w bezpośrednim sąsiedztwie uczelni, a więc grupują się na określonych obszarach, często w centrum miast. Analogicznie może być, gdy idzie o opanowanie określonych segmentów rynku pracy przez studentów. Masowa skłonność do podejmowania pracy oddziałuje na poziom płac, to z kolei wpływa na konkurencyjność poszczególnych rynków i warunki pracy. Bez większego ryzyka można uznać, że pozycja studentów jako pracowników wobec innych zatrudnionych jest szczególna choćby ze względu na seku ndarny charakter ich pracy. Przy czym przez „sekundarność” należy rozumieć stosunkowo wąski zakres obowiązków i jednocześnie słabą pozycję w miejscu pracy (często odpowiadającą tzw. fordowskiemu modelowi motywowania), brak doświadczenia oraz specyfikę zapotrzebowania na kwalifikacje. Można na zasadzie hipotezy zasugerować, że w Europie Środkowej studenci zajmują podobne miejsce jak migranci w bogatszych gospodarkach zachodniej i południowej Europy ${ }^{23}$. Trzeba też pamiętać, że praca nie stanowi głównego składnika roli studenta.

Status ekonomiczny zbiorowości studentów jest wypadkową co najmniej trzech elementów: (1) daniny rodziców (nie ma wystarczających danych, by

${ }^{22}$ W tym specyficznej kultury spędzania czasu wolnego i związanej z tym „karnawalizacji” rozwoju skierowanej właśnie do użytkowników zewnętrznych oferty nieodpłatnego uczestnictwa, połączonego na przykład z promocją określonych postaw.

${ }^{23}$ Co ilustrują niższe wskaźniki bezrobocia wśród osób młodych w naszej części Europy (por. dane Eurostatu: Unemployment Statistics, tabela 1: Youth unemployment, 2014Q4 (\%) (http://ec. europa.eu/eurostat/statistics-explained/index.php/File:Table_1_Youth_unemployment,2014Q4_ (\%25).png [marzec 2016]. 
szacować zakres tych transferów, nazwijmy je międzypokoleniowymi); (2) systemu wsparcia stypendialnego oferowanego przez władzę publiczną $\mathrm{W}$ formie finansowania szkolnictwa publicznego. Jest to forma redystrybucji opartej na kryteriach socjalnych i związanych z osiągnięciami samych studentów (tutaj dane są dostępne, ich udział w całkowitym dochodzie pozostaje jednak nieznany). O studenckich dochodach z pracy wiemy najmniej. Jednak dopiero całkowita suma dochodów stanowi podstawę do interpretacji zasadności tez mówiących o prekaryzacji młodego pokolenia, daje również podstawy do uchwycenia specyfiki segmentów rynku pracy, na którym studenci odgrywają znaczącą rolę.

Pewne światło na ten problem rzuca referowane tu badanie zrealizowane przez pracowników Uniwersytetu Ekonomicznego w Poznaniu. Na podstawie ankiety ustalili oni (Gaczek, Kaczmarek 2015, ryc. 42, s. 141), że podstawowe elementy budżetu studentów to środki od rodziców (szacowane średnio na 574 zł) i środki uzyskane z pracy (776 zł). Przy czym te pierwsze uzyskuje $86,4 \%$ studentów, te drugie zaś już jedynie $15,6 \%$. Kolejne przychody są związane $z$ formami transferów środków publicznych, średnio to: 339 zł stypendium socjalnego oraz 297 stypendium za dobre wyniki. Znaczące pozycje dochodowe (dotyczące jednak znaczniej mniejszych grup studentów, bo co dwudziestego i co czterdziestego) to: renta i kredyt studencki. Po zsumowaniu dwóch głównych źródeł dochodów (pracy i dotacji rodziców lub środków stypendialnych uczelni) okazuje się, że studenci dysponują sumą nieco przekraczającą 1200 zł miesięcznie, co lokuje ich niezwykle nisko w hierarchii dochodowej, tym bardziej że mówimy o uwarunkowaniach typowych dla miasta (a często centrum miasta), gdzie koszty utrzymania są relatywnie wysokie. Istotne jest pytanie o specyfikę oddziaływania grupy, której status ekonomiczny jest tak niski.

Jak można sądzić na podstawie wyników badania: studenci raczej nie oddziałują $\mathrm{w}$ sposób zasadniczy na rynek pracy, zwłaszcza jeżeli ich zatrudnienie ma charakter rozproszony i „elastyczny”. Pogłębione wnioski wymagają jednak bardziej szczegółowej analizy, nie tylko stwierdzenia faktu zatrudnienia, ale również ustalenia miejsca tego zatrudnienia, warunków pracy czy formy prawnej zatrudnienia. Warto w tym miejscu sformułować kolejne dwie hipotezy inspirujące do podjęcia badań, a mianowicie: (5) ma sowa obecność studentów oddziałuje na rynek pracy, co można obserwować na podstawie specyfiki dominujących form zatrudnienia oraz wysokości wynagrodzeń; (6) studenci wykazują tendencję do grupowania się na rynku pracy w określonych sektorach i przy wykonywaniu pracy określonego typu.

Druga hipoteza zapewne jest łatwiejsza do zweryfikowania, pierwsza zaś jest kluczowa dla interpretacji oddziaływania studentów na lokalne gospodarki miejskie, gdy analizujemy na przykład siłę nabywczą mieszkańców i poziom bezrobocia, a jednocześnie uruchamia dyskusję na temat potencjału ożywiania miasta przez studentów. 


\section{PROPOZYCJA REKONCEPTUALIZACJI I REKOMENDACJE BADAWCZE}

Można założyć, że obraz ewolucji znaczenia wiedzy i miejsca jej nabywania powinien uwzględniać nie tylko chronologicznie wcześniejsze doświadczenia zachodnioeuropejskie. W Europie Środkowej warianty tego procesu realizują się z pewnym opóźnieniem, ale o jego znaczeniu mogą przekonywać: (1) dynamika rozwoju i kierunek ewolucji rodzącego się na początku lat dziewięćdziesiątych XX wieku niepublicznego szkolnictwa wyższego (i rosnąca pozycja szkół niepublicznych na rynku edukacyjnym), (2) wzrost znaczenia nielicznych silnych organizacji uniwersyteckich oraz (3) rosnący udział studentów zagranicznych, którzy „kupują” kwalifikacje według kryteriów ceny i jakości, niejako poza kontekstem narodowym.

Warto dostrzec, że związek między procesem urynkowienia wiedzy a wskaźnikami skolaryzacji nie musi być oczywisty. Na podstawie rozpowszechnionych interpretacji socjologicznych można przyjąć, że czynnikiem pośredniczącym jest nawiązanie do rozumianej po weberowsku etyki pracy, w myśl której wykonywanie wyspecjalizowanej pracy rozpatrywane jest jako czynnik etyczny dynamizujący system kapitalistyczny. Według Webera (2014) dzieje się tak na podstawie zakwestionowania przez wspólnoty protestanckie dualizmu etyki religijnej i etyki bogacenia się oraz uznania, że wiedza i wyspecjalizowane kompetencje stanowią wskaźnik cywilizacyjnej ewolucji w kierunku wyspecjalizowanej pracy. Taki sposób myślenia odnajdujemy w wielu analizach, jeszcze $z$ lat dziewięćdziesiątych XX wieku, gdy zmiana stosunku Polaków do pracy i pojawienie się na przykład ryzyka utraty pracy (bezrobocia) znamionowały postępujące dopasowywanie się do reguł nowej rzeczywistości (zob. Ziółkowski, Pawłowska, Drozdowski 1994). Podobną perspektywę poznawczą da się śledzić w nowszych opracowaniach — choćby Henryka Domańskiego $(2008,2009)$ - w których głównym elementem opisu procesu społecznego są znamiona postępującej merytokratyzacji, a przyrastanie kompetencji (kapitału edukacyjnego Polaków), ale również narastanie nierówności dochodowych (jako wskaźnika dynamiki procesu), jest postrzegane jako ilustracja tej samej tendencji, która prowadzi do powołania do życia konkurencyjnego społeczeństwa kapitalistycznego, z tzw. nową klasą średnią w roli głównego aktora społecznego (zob. Burris 1986).

Przedmiotem dyskusji może być adekwatność tej wizji do realności społeczeństw postkomunistycznych i środkowoeuropejskich miast, w której anglosaski obraz genezy klasy średniej oparty na zasadzie mortgage loan (kredytu hipotecznego jako źródła masowej prywatnej własności) da się obserwować co najwyżej wyspowo i w powiązaniu $z$ aktualną polityką sektora bankowego oraz w odniesieniu do określonych segmentów rynku pracy, dla których charakterystyczna jest nie wysoka średnia, lecz mediana dochodów (bo na nią oddziałują bardzo znaczące różnice między wysokimi a niskimi dochodami). Zgodnie $z$ taką interpretacją masowe studiowanie mogłoby być (i mógłby to być choć- 
by przykład Lublina) wskaźnikiem pewnego rodzaju rozpowszechnionej, prospektywnej woli uzyskania wyspecjalizowanej pozycji zawodowej i stylu życia klasy średniej, co ma szanse urzeczywistnić się w warunkach konkretnej społeczności i konkretnego rynku pracy. Używając jeszcze innego języka: owa alternatywna interpretacja byłaby „instytucjonalnym” (w rozumieniu instytucji zaczerpniętym od tzw. starych instytucjonalistów; zob. Veblen 1971), a zatem świadomościowym wyobrażeniem na temat rzeczywistości wiążącym dyplom wyższej uczelni z wysoką pozycją zawodową i majątkową.

Przesunięcie akcentu $\mathrm{z}$ synchronicznego determinizmu wpisanego $\mathrm{w}$ obraz postępującej kapitalistycznej merytokracji („klasowości” awansu społecznego) w kierunku analizy fenomenu świadomości społecznej i woli może pomóc zrozumieć specyfikę zjawiska, które odrywa decyzje edukacyjne od materialnych podstaw (np. siatki płac oferowanych realnie absolwentom po zakończeniu studiów). Fenomen taki można określić mianem studentyfikacji świadomości społecznej, wzmacnianej przez polityki publiczne, a bardzo znaczącą obecność studentów w miastach jako studentyfikację miast. Uzyskamy dzięki temu przestrzeń do stawiania nowych pytań, a precyzyjniej — do spojrzenia na zjawisko upowszechnienia wyższego wykształcenia $z$ innej „kauzalnej" i jednocześnie krytycznej strony.

$\mathrm{Z}$ tego punktu widzenia finansowane za publiczne pieniądze studiowanie oraz studia na uczelniach niepublicznych (finansowane przez samych zainteresowanych) stają się czynnikiem towarzyszącym zmianom w centrach miast, zmianom, które często bezkrytycznie uznajemy za pozytywne i oczekiwane. W praktyce często mamy jednak do czynienia z problemem „rozwoju niedorozwoju" centrów (tak jest w choćby w przywoływanym przykładzie Poznania).

Powtórzmy zatem pytanie, jakie jest oddziaływanie studentów na funkcjonowanie i przestrzenie miast? Odpowiedź jest złożona. Wiemy już, że masowa obecność studentów, ich niskie dochody (z pracy, $z$ dotacji rodziców czy donatorów publicznych) mogą stanowić nie potencjalną dźwignię gentryfikacji (lub rewitalizacji), lecz czynnik stabilizujący lub zamrażający aktualny stan rzeczy w jego kontrowersyjnym kształcie, co wiąże się na przykład z postępowaniem zjawisk suburbanizacji, a nie ich osłabianiem. Niska jakość zamieszkania, gdy głównym walorem są niskie koszty dla najemców, niezdolność do podtrzymywania sfery usług wykraczających poza to, co oferują puby czy siłownie (zgodnie $z$ deklaracjami samych studentów), stają się barierą, a nie zasobem, mogą być czynnikiem pogłębiania dewaloryzacji, a nie ożywiania. Jednocześnie zarejestrowane dane podważają tendencje gentryfikacyjne, jakie przypisuje się obecności studentów w mieście.

Reasumując należy stwierdzić, że studentyfikacja, chociaż generuje ją docenienie statusu wiedzy, nie musi być czynnikiem rozwojowym, pozostaje jednak istotnym elementem podtrzymującym budżety współczesnych miast (dobrze ilustrują to przywołane sumy wydatkowane przez studentów na pokrycie kosztów zamieszkania i wyżywienia). 
Weryfikacja zaproponowanej listy hipotez pozwoli uwarunkowania studentyfikacji opisać bardziej systematycznie i dostrzec przy tym również koszty subsydiowanej z publicznych środków komodyfikacji wiedzy i koszty masowej reakcji na mityzację kapitału edukacyjnego w mieście, uruchamiającej zarówno szanse, jak i zagrożenia. Zaproponowane wnioski należy postrzegać nie jako gotowy „krytyczny światopogląd”, lecz jako zaproszenie do dyskusji, której rezultatem powinny być badania i bardziej refleksyjna oraz zrównoważona polityka miast.

\section{BIBLIOGRAFIA}

Bauman Zygmunt, 1999, Globalizacja. I co z tego dla ludzi wynika, tłum. Ewa Klekot, Państwowy Instytut Wydawniczy, Warszawa.

Beck Ulrich, 2002, Społeczeństwo ryzyka. W drodze do innej nowoczesności, tłum. Stanisław Cieśla, Scholar, Warszawa.

Brzechczyn Krzysztof, 1998, Odrębność historyczna Europy Środkowej. Studium metodologiczne, Humaniora, Poznań.

Bugaj Justyna M., Godzwon Zofia, Lis Aleksandra, Rybkowski Radosław, Pilch Mariusz, 2012, Wpływ sektora szkolnictwa wyższego na Produkt Krajowy Brutto, Centrum Badań nad Szkolnictwem Wyższym UJ, Kraków (http://www.ncbir.pl/gfx/ncbir/userfiles/_public/fundusze_europej skie/infrastruktura_i_srodowisko/ewaluacja/wplyw_szkolnictwa_wyzszego_na_pkb_040712_1. pdf).

Burris Val, 1986, The Discovery of the New Middle Class, „Theory and Society”, t. 15, s. 317-349.

Bures Regina M., Cain Colleen, 2008, Dimensions of Gentrification in a Tourist City, Princeton (materiał konferencyjny, http://paa2008.princeton.edu/papers/81623).

Castells Manuel, 1982, Kwestia miejska, tłum. Bohdan Jałowiecki, Jacek Piątkowski, Państwowe Wydawnictwo Naukowe, Warszawa.

Domański Henryk, 2008, Merytokracja w zasadach dystrybucji wynagrodzeń w latach 1982-2005, w: Henryk Domański (red.), Zmiany stratyfikacji społecznej w Polsce, Wydawnictwo IFiS PAN, Warszawa.

Domański Henryk, 2009, Stratyfikacja a system społeczny w Polsce, „Ruch Prawniczy, Ekonomiczny i Socjologiczny", nr 2.

Fabula Szabolcs, Horvath Daniel, Soros Lajos, Kovacs Zoltan, 2015, Urban Diversity and the Production of Public Spa ces in Budapest (materiał konferencyjny, http://www.urrlab.cz/sites/default/files/ cat-finalprogramme.pdt).

Filiciak Mirosław, Danielewicz Michał, Halawa Mateusz, Mazurek Paweł, Nowotny Agata, 2010, Młodzi i media. Nowe media a uczestnictwo w kulturze. Raport Centrum Badań nad Kulturą Popularną SWPS, Warszawa.

Fleissner Peter, 2009, The 'Commodification' of Knowledge in the Global Information Society, „tripleC”, t. 7 , nr 2 .

Gaczek Wanda Maria, Kaczmarek Mirosława, 2015, Poznański ośrodek akademicki. Zachowania konsumenckie studentów, Bogucki Wydawnictwo Naukowe, Poznań.

Gdula Maciej, Sadura Przemysław (red.), 2012, Style życia i porzadek klasowy w Polsce, Scholar, Warszawa.

Gołębiowski Grzegorz, 2007, Modele kapitalizmu a kierunek rozwoju gospodarczego Polski, „Współczesna Ekonomia", t. 1, nr 3.

Jencks Charles, 1986, What Is Post-Modernism?, St Martin's,. New York. 
Kauppinen Ilkka, 2014, Different Meanings of 'Knowledge as Commodity' in the Context of Higher Education, „Critical Sociology”, t. 40, s. 393-409.

Kolasa-Nowak Agnieszka, 2011, W kierunku krytycznej socjologii transformacji? Nastawienia poznawcze $w$ autoportrecie polskich socjologów, „Zeszyty Naukowe Uniwersytetu Szczecińskiego. Studia Sociologica", nr 21.

Krajewski Marek, 2013, W kierunku relacyjnej koncepcji uczestnictwa w kulturze, „Kultura i Społeczeństwo", nr 1.

Kwiek Marek, 2006, The University and The State: A Study into Global Transformations, Peter Lang, Frankfurt am Main-New York.

Lallement Michel, 2012, Europe and the Economic Crisis: Forms of Labour Market Adjustmen and Varieties of Capitalism, „Work, Employment and Society”, t. 25, nr 4.

Martinotti Guido, 1996, The New Social Morphology of Cities, „Management of Social Transformations - MOST Discussion Paper Series", nr 16.

Piketty Thomas, 2015, Kapitat w XXI wieku, tłum. Andrzej Bilik, Wydawnictwo Krytyki Politycznej, Warszawa.

Radder Hans, 2010, The Commodification of Academic Research: Science and the Modern University, University of Pittsburgh Press, Pittsburgh.

Rybicki Paweł, 1979, Struktura społecznego świata, Państwowe Wydawnictwo Naukowe, Warszawa.

Smith Darren P., 2005, 'Studentification': The Gentrification Factory?, w: Rowland Atkinson, Gary Bridge (red.), Gentrification in a Global Context: The New Urban Colonialism, Routledge, London.

Smith Darren P., Holt Louise, 2007, Studentification and 'Apprentice' Gentrifiers within Britain's Provincial Towns and Cities: Extending the Meaning of Gentrification, „Environment and Planning A”, t. 39.

Smith Darren P., Hubbard Phil, 2014, The Segregation of Educated Youth and Dynamic Geographies of Studentification, „Area”, t. 46, nr 1, s. 92-100.

Snowdon Brian, 2006, The Enduring Elixir of Economic Growth Xavier Sala-i-Martin on the Wealth and Poverty of Nations, „World Economics”, t. 7, nr 1.

Standing Guy, 2014, Prekariat: nowa niebezpieczna klasa, tłum. zbiorowe, Wydawnictwo Naukowe PWN, Warszawa.

Urbański Jarosław, 2014, Prekariat i nowa walka klas. Przeobrażenia wspótczesnej klasy pracowniczej i jej form walki, Książka i Prasa, Warszawa.

Urquhart Michael, 1984, The Employment Shift to Services: Where Did It Come From?, „Monthly Labor Review", kwiecień.

Wallerstein Immanuel, 2004, Koniec świata jaki znamy, tłum. zbiorowe, Scholar, Warszawa.

Weber Max, 2014, Etyka protestancka a duch kapitalizmu. Protestanckie „sekty” a duch kapitalizmu, tłum. Bogdan Baran, Jan Miziński, Aletheia, Warszawa.

Veblen Thorstein, 1971, Teoria klasy próżniaczej, tłum. Janina i Krzysztof Zagórscy, Państwowe Wydawnictwo Naukowe, Warszawa.

Ziółkowski Marek, Pawłowska Barbara, Drozdowski Rafał, 1994, Jednostka wobec władzy, Nakom, Poznań.

Znanicki Florian, 1997, Społeczna rola studenta uniwersytetu, Nakom, Poznań.

\section{STUDENTIFICATION-RECONCEPTUALIZATION OF THE IDEA AND RESEARCH HYPOTHESES}

\section{Summary}

The author outlines the potential research field demarcated by the phenomenon of the mass presence of students in the public space. At the same time, he views the 
phenomenon of studentification on a broader scale than solely the Polish (or Eastern European) one, treating the local situation as a case study. On the basis of the available literature he presents successive elements in the contemporary process of change: (a) the evolution of the status of knowledge; (b) change in the idea of the urban environment, as shown by the growth of students' importance in the urban space; and (c) making the labour market selectively flexible on account of the significant group of working students. The author formulates hypotheses for each of these areas, and then makes general recommendations for researchers into the phenomenon of studentification.

Key words / słowa kluczowe

student / student; studentyfication / studentyfikacja; labour market / rynek pracy; city / miasto 